\title{
POLITIK MAHAR DI INDONESIA Antara Ada dan Tiada
}

\author{
Anak Agung Ngurah Agung Wira Bima Wikrama \\ Fakultas Ilmu Sosial dan Ilmu Politik, Universitas Mahendradatta, Denpasar \\ E-mail:bimawikrama65.gmail.com
}

\begin{abstract}
Abstrak - Partai politik merupakan institusi satu-satunya yang berhak mengusulkan calon presiden dan wakil presiden seperti yang diatur dalam Pasal 6A ayat 2 UUD 1945 sehingga nantinya memiliki kekuasaan dan legitimasi sebagai kepala negara dan kepala pemerintahan. Hak konstitusional tersebut tidak dimiliki oleh lembaga demokrasi manapun selain partai politik. Namun dalam proses penyelenggaraan pemilihan umum tersebut tidak selalu berjalan sesuai dengan yang diharapkan seperti tertulis dalam undang-undang dan aturan KPU. Terjadi penyimpangan yang dilakukan oleh calon maupun oleh partai politik berupa Mahar Politik.

Mengingat peristiwa mahar politik tersebut berada pada wilayah pemilihan umum maka berdasarkan prinsip hukum berupa Lex specialis derogat legi generali yang menyatakan bahwa hukum yang bersifat khusus (lex specialis) mengesampingkan hukum yang bersifat umum (lex generalis) maka peristiwa Mahar Politik diselesaikan oleh sebuah lembaga yaitu Bawaslu (Badan Pengawas Pemilihan Umum).

Selain Pasal 6A ayat 2 UUD 1945, terdapat pula UU Nomor 10 Tahun 2016 Tentang Perubahan kedua atas undang-undang nomor 1 tahun 2015 Tentang penetapan Perppu Nomor 1 tahun 2014 tentang pemilihan gubernur, bupati, dan walikota khususnya pada Pasal 47, Pasal 187A, Pasal 187B, Pasal 187C dan Pasal 187D yang mengatur tentang pemilihan umum. Namun kenyataannya banyak terjadi penyimpangan dalam pelaksanaan UUD dan UU tersebut.

Peristiwa berupa mahar politik tetap saja terjadi yang dibuktikan dari keterangan yang diberikan oleh beberapa saksi dan merupakan korban sekaligus pelaku dari mahar politik tersebut. Mengherankan lagi, Bawaslu sebagai lembaga pengawas pemilu yang diberi amanat oleh UU untuk menegakkan aturan yang berlaku sangat sulit untuk menjalankan tugasnya mengingat Bawaslu memiliki kelemahan dalam penanganan dugaan mahar politik tersebut. Kelemahan Bawaslu adalah, mereka tidak punya daya paksa untuk menghadirkan saksi atau orang yang mau dimintai keterangan.

Penulis berpendapat bahwa perlu adanya payung hukum berupa undang-undang yang memberikan peluang yang lebih tegas kepada Bawaslu sehingga kedudukan Bawaslu sebagai badan pengawas pemilu dapat lebih kuat.
\end{abstract}

Kata Kunci: Politik, Mahar.

Abstract - Political parties are the only institution that has the right to propose candidates for president and vice president as stipulated in Article 6A paragraph 2 of the 1945 Constitution so that they will have power and legitimacy as heads of state and heads of government. These constitutional rights are not owned by any democratic institution other than political parties. However, in the process of holding the general election, it does not always go as expected, as stated in the KPU's laws and regulations. There were irregularities committed by candidates and by political parties in the form of Money Politics.

According to the political dowry event is in the general election area based on the legal principle of Lex specialis derogat legimitation generaly which states that the law is specific (lex specialis) overrides the general law (lex generalis) the Money Politic event is resolved by an institution, namely Bawaslu (General Election Supervisory Board).

Besides the Article 6A paragraph 2 of the 1945, there is also Law Number 10 of 2016 concerning the Second Amendment of Law No. 1 in 2015 concerning the stipulation of Perppu (the governmental regulation of low amandement) Number 1 in 2014 according to the governor's election, regents and mayors, especially in Article 47, Article 187A, 
Article 187B, Article 187C and Article 187D which regulates general elections. But in reality there are many irregularities in the implementation of the Constitution and etc.

Events in the form of political dowry still occured which is evidenced by the information given by several witnesses and as the victim and perpetrator of the political dowry. Surprisingly, the General Election Supervisory Board (Bawaslu) as an election watchdog institution mandated by the Act to enforce the prevailing regulations is very difficult to carry out its duties, reminding that Bawaslu has weaknesses in handling the alleged political dowry. The weakness of Bawaslu is that they do not have the power to take witnesses or people who will be questioned.

The author argues that there is a need for a legal protection in the form of a law that provides better opportunities to Bawaslu so that the position of Bawaslu as an election supervisory bord can be much stronger.

Keywords: money , politics

\section{Latar Belakang}

Dalam sistem ketatanegaraan, partai politik memiliki kedudukan dan peran yang sangat penting dan strategis. Partai politik merupakan institusi satu-satunya yang berhak mengusulkan calon presiden dan wakil presiden seperti yang diatur dalam Pasal 6A ayat 2 UUD 1945 sehingga nantinya memiliki kekuasaan dan legitimasi sebagai kepala negara dan kepala pemerintahan. Hak konstitusional tersebut tidak dimiliki oleh lembaga demokrasi manapun selain partai politik.

Seorang tokoh politik, kharismatik, populer, dan atau tokoh yang memiliki tingkat elektoral tinggi hanya dapat bermimpi untuk menjadi Presiden, Gubernur, Bupati atau Walikota. Tetapi jika partai politik tidak mengusulkannya dalam pemilihan umum maka mimpi tersebut tidak akan terjadi.

Namun dalam proses penyelenggaraan pemilihan umum tersebut tidak selalu berjalan sesuai dengan yang diharapkan seperti tertulis dalam undang-undang dan aturan KPU. Terjadi penyimpangan yang dilakukan oleh calon maupun oleh partai politik berupa Mahar Politik. Mahar politik dapat digolongkan peristiwa pidana, sama seperti pidana umum lainnya karena telah terjadinya peristiwa penyuapan atau pemberian yang mengakibatkan sistem atau aturan tidak berjalan secara normal. Mengingat peristiwa mahar politik tersebut berada pada wilayah pemilihan umum maka berdasarkan prinsip hukum berupa Lex specialis derogat legi generali yang menyatakan bahwa hukum yang bersifat khusus (lex specialis) mengesampingkan hukum yang bersifat umum (lex genera- lis) maka peristiwa Mahar Politik diselesaikan oleh sebuah lembaga yaitu Bawaslu (Badan Pengawas Pemilihan Umum).

\section{Landasan Teori \\ 2.1 Teori Materialisme Historis}

Kata materialisme dalam Kamus Besar Bahasa Indonesia (KBBI) dapat diartikan sebagai pandangan hidup yang mencari dasar segala sesuatu yang termasuk kehidupan manusia di dalam alam kebendaan semata-mata dengan mengesampingkan segala sesuatu yang mengatasi alam indra. Dapat pula diartikan sebagai pandangan manusia terhadap segala sesuatu berdasarkan terhadap kebendaan atau materi semata-mata untuk memuaskan indra. Historis dapat diartikan sebagai sesuatu yang berkaitan dengan masa sebelumnya atau lampau. Jadi Meterialime Historis dapat diartikan sebagai pandangan manusia terhadap segala sesuatu berdasarkan terhadap kebendaan atau materi dengan melihat keadaan masyarakat yang terjadi sebelumnya untuk mengejar kepuasan indra.

Berdasarkan penjelasan di atas dapat dikatakan bahwa memberi atau menerima segala sesuatu untuk kepentingan tertentu tanpa mengindahkan atau memperhatikan aturan yang berlaku dengan tujuan untuk pemuasan indra dapat dikatakan sebagai meterialisme. Peristiwa ini terjadi karena adanya konstruksi budaya materialisme yang sebelumnya telah terjadi dan dianggap benar. Kesalahan yang dilakukan terus menerus tanpa ada sangsi akan menjadi budaya dan lambat laun akan menjadi kebenaran.

Realitas di atas ditangkap oleh Karl 
Marx dengan teorinya yang terkenal yaitu Teori Materialisme Historis. Karl Marx mengungkap bahwa bukanlah ide yang akan menentukan realitas akan tetapi realitas sosial yang akan menentukan cara bagaimana manusia berpikir dan bekerja atau berproduksi. Cara berproduksi manusia yang akan menentukan interaksi dan hubungan sosial di lingkungannya. Marx juga berpendapat bahwa insititusi-institusi dan lembaga-lembaga negara bergantung pada kondisi ekonomi sebagai pendorong utama penciptaan struktur sosial yang begitu luas. Seperti kapitalisme yang menciptakan hasrat terhadap uang dan barang serta penindasan terhadap buruh yang tidak mempunyai alat-alat produksi.

Sangat jelas diungkapkan oleh Karl Marx bahwa pendorong utama materialisme adalah kapitalisme yang mendorong hasrat terhadap uang dan barang untuk memuaskan indra. Terjadinya mahar politik, antara lain juga disebabkan oleh materialisme yang mendorong adanya hasrat untuk mendapatkan uang dan barang untuk memuaskan indra.

\subsection{Teori Sosiologi Hukum}

Dari sudut sejarah, sosiologi hukum untuk pertama kalinya diperkenalkan oleh seorang Itali yang bernama Anzilotti pata tahun 1882. Sosiologi hukum pada hakekatnya lahir dari hasil-hasil pemikiran para ahli, baik di bidang filsafat hukum, ilmu maupun sosiologi. Hasil-hasil pemikiran tersebut tidak saja berasal dari individu-individu tetapi mungkin pula besaral dari aliran-aliran yang mewakili sekelompok ahli pemikir, yang secara garis besar mempunyai pendapat yang berbeda.

Secara etimologis, sosiologi berasal dari kata latin, socius yang berarti kawan dan kata Yunani logos yang berarti kata atau berbicara. Jadi sosiologi adalah berbicara mengenai masyarakat.

Sosiologi hukum saat ini sedang berkembang pesat. Ilmu ini diarahkan untuk menjelaskan hukum positif yang berlaku (artinya isi dan bentuknya yang berubah-rubah menurut waktu dan tempat), dengan bantuan faktor-faktor kemasyarakatan. Tetapi disatu sisi hukum itu sendiri dijelaskan dengan bantuan hukum. Dalam dua hal itu, hukum dan dinamika kemasyarakatan diletakkan pada suatu ta- taran yang sama.

Pemikiran sosiologi hukum lebih berfokus pada keberlakuan empiris atau faktual dari hukum. Hal ini, memperlihatkan bahwa sosiologi hukum tidak secara langsung diarahkan pada hukum sebagai sistem konseptual, melainkan pada kenyataan sistem kemasyarakatan yang idalamnya hukum hadir sebagai pemeran utama. Objek tingkatan kedua adalah kaidah-kaidah hukum.

Hal tersebut di atas berbeda dengan ilmu hukum normatif, yang memandang hukum dalam hukum itu sendiri (apa yang tertuang dalam peraturan). Eksponen dari aliran positifisme John Austin, mengatakan bahwa studi tentang filsafat hukum seharusnya merupakan studi tentang hukum yang benar-benar terdapat dalam sistem hukum, dan bukan hukum yang seharusnya ada dalam norma-norma moral (Achmad Ali, Sosiologi Hukum, hal 9).

Berbeda dengan hal tersebut, sosiologi hukum memandang hukum dari luar hukum. Dalam hal ini, sosiologi hukum mencoba untuk memperlakukan sistem hukum dari sudut pandang ilmu sosial. Pada dasarnya, sosiologi hukum berpendapat bahwa hukum hanyalah salah satu dari banyak sistem sosial dan bahwa justru sistem-sistem sosial lain, yang terdapat di dalam masyarakat, memberi arti dan pengaruh terhadap hukum.

Seorang ahli filsafat berkebangsaan Perancis bernama Aguste Cumte pada abad ke-19, menulis beberapa buah buku untuk mempelajari masyarakat. Dia berpendapat bahwa ilmu sosial mempunyai urutan tertentu berdasarkan logika metode ilmiah dan bahwa setiap penelitian dilakukan melalui tahap-tahap tertentu untuk mencapai tahap akhir. Dia beranggapan bahwa saatnya telah tiba bagi kesahihan ilmiah terhadap penelitian kemasyarakatan. Sejak saat itu Comte memperkenalkan sosiologi sosial sebagai ilmu pengetahuan kemasyarakatan. Bagi Comte, sosiologi merupakan ilmu pengetahuan kemasyarakatan umum, yang merupakan hasil akhir dari perkembangan ilmu pengetahuan. Oleh karena itu, sosiologi didasarkan pada kemajuan yang telah dicapai oleh ilmu pengetahuan sebelumnya. Selain itu Comte mengatakan bahwa sosiologi harus dibentuk berdasarkan pengamatan dan tidak pada spekulasi keadaan masyarakat 
(Comte dalam Pengantar Sosiologi $\mathrm{Hu}-$ kum, 1-2).

Dari uraian di atas dapat dikatakan bahwa segala peristiwa yang terjadi di Indonesia erat kaitannya dengan masyarakat Indonesia. Demikian pula dasar-dasar berpikir dari Comte melalui teori Sosiologi Hukum merupakan panduan bagi penulis dalam melakukan penelitian ini. Di sisi lain, pendidikan hukum saat ini cenderung berorientasi kepada kuhum tertulis, yang selalu mementingkan aturan dan keteraturan. Keteraturan hukum merupakan sebuah keharusan guna mewujudkan rasa percaya terhadap hukum dan kepastian terhadap hukum. Hal ini sangat jelas tertulis dalam sistim ketatanegaraan di Negara Republik Indonesia dimana Pancasiila dan Undang Undang Dasar 1945 merupakan sumber dari segala sumber hukum. Segala aturan dan perundang-undangan yang ada maupun yang akan dibuat tidak boleh bertentangan dengan Pancasila dan Undang-Undang Dasar 1945.

Dari penjelasan di atas dapat dikatakan bahwa pelaksanaan hukum harus dapat diimplementasikan dalam semua kegidupan masyarakat dan tidak dapat ditafsirkan lain kecuali tafsir hukum itu sendiri. Pelaksanaan hukum harus dapat mewujudkan tata kelola pemerintahan dan kehidupan masyarakat yang benar dan bukan dibenarkan akibat dari konstruksi budaya yang keliru. Termasuk di dalamnya adalah hukum harus dapat mencegah terjadinya implementasi yang terus menerus terhadap budaya mahar politik yang terjadi di Indonesia.

\section{Pembahasan}

\subsection{Politik Mahar di Indonesia.}

Dalam sistem ketatanegaraan, partai politik memiliki kedudukan dan peran yang sangat penting dan strategis. Partai politik merupakan institusi satu-satunya yang berhak mengusulkan calon presiden dan wakil presiden seperti yang diatur dalam Pasal 6A ayat 2 UUD 1945 sehingga nantinya memiliki kekuasaan dan legitimasi sebagai kepala negara dan kepala pemerintahan. Hak konstitusional tersebut tidak dimiliki oleh lembaga demokrasi manapun selain partai politik.

Seorang tokoh politik, kharismatik, populer, dan atau tokoh yang memiliki tingkat elektoral tinggi hanya dapat ber- mimpi untuk menjadi Presiden, Gubernur, Bupati atau Walikota. Bila partai politik tidak mengusulkannya dalam pemilihan umum maka mimpi tersebut tidak akan terjadi.

Penulis mengambil sebuah contoh yaitu Akbar Tanjung, yang sejak awal menjadi politikus, menteri tiga kali, ketua umum partai, ketua DPR dan malang melintang di dunia aktivis mulai dari ketua umum PB HMI, pendiri kelompok Cipayung (HMI, PMII, GMKI, PMKRI dan GMNI) serta pencetus lahirnya KNPI dan AMPI sampai sekarangpun tidak pernah menjadi calon presiden karena tidak diusulkan oleh partai politik.

\subsection{Undang-Undang Pemilihan Umum Indonesia}

Sistem ketatanegaraan yang berlaku di Indonesia mengamanatkan bahwa, partai politik memiliki kedudukan dan peran yang sangat penting dan strategis. Disebutkan bahwa Partai politik merupakan institusi satu-satunya yang berhak mengusulkan calon presiden dan wakil presiden seperti yang diatur dalam Pasal 6A ayat 2 UUD 1945. Adapun Pasal 6A yang dimaksud adalah:

\section{Pasal 6A}

(1) Presiden dan Wakil Presiden dipilih dalam satu pasangan secara langsung oleh rakyat. $* * *)$

(2) Pasangan calon Presiden dan Wakil Presiden diusulkan oleh partai politik atau gabungan partai politik peserta pemilihan umum sebelum pelaksanaan pemilihan umum.***)

(3) Pasangan calon Presiden dan wakil Presiden yang mendapatkan suara lebih dari lima puluh persen dari jumlah suara dalam pemilihan umum dengan sedikitnya dua puluh persen suara disetiap provinsi yang tersebar di lebih dari setengah jumlah provinsi di Indonesia, dilantik menjadi Presiden dan Wakil Presiden.***)

(4) Dalam hal tidak ada pasangan calon Presiden dan Wakil Presiden terpilih, dua pasangan calon yang memperoleh suara terbanyak pertama dan kedua dalam pemilihan umum dipilih oleh rakyat secara langsung dan pasangan yang memperoleh suara rakyat terbanyak dilantik sebagai Presiden dan Wakil Presiden.****) 
(5) Tata cara pelaksanaan pemilihan Presiden dan Wakil Presiden lebih lanjut diatur dalam undang-undang.***)

Staf Ahli Bidang Pemerintahan Kemendagri, Suhajar Diantoro, mengatakan bahwa mahar politik merupakan racun dalam demokrasi.

"praktik demokrasi dalam proses pemilihan kepala daerah melalui pemilihan umum terciderai bila dilakukan dengan mahar politik. Sebab, mahar politik merupakan tindak pidana. Mahar politik adalah racun di dalam pelaksanaan demokrasi kita. Sanksi untuk yang melakukan mahar politik jelas, yakni penjara 72 bulan plus denda maksimal Rp 1 miliar. Namun masih ada yang berani melakukam praktik mahar. Biaya politik, memang ada. Namun, hanya pada batasan tertentu hal itu diperbolehkan. Saya menyadari, bantuan dana untuk partai politik masih kecil. Persentasenya di APBN nilainya hanya 0,016 persen. Padahal parpol ini adalah sebuah institusi yang dibangun dan fokus untuk pembangunan politik dalam negara demokrasi. Karena itu, sebagai bentuk dukungan dan memperkuat partai politik, pemerintah menaikan dana parpol Rp 108 per suara ke Rp 1.000 persuara. Kenapa, karena sesungguhnya dalam demokrasi, parpol itu jembatan penghubung antara rakyat dan pemerintah".

Pendapat tersebut sangat relefan dengan aturan yang tertuang dalam Undang-Undang Nomor 10 Tahun 2016 Tentang Perubahan kedua atas undang-undang nomor 1 tahun 2015 Tentang penetapan peraturan pemerintah pengganti undangundang Nomor 1 tahun 2014 tentang pemilihan gubernur, bupati, dan walikota. Adapun pasal-pasal yang dimaksud adalah:

\section{Pasal 187A}

(1) Setiap orang yang dengan sengaja melakukan perbuatan melawan hukum menjanjikan atau memberikan uang atau materi lainnya sebagai imbalan kepada warga negara Indonesia baik secara langsung ataupun tidak langsung untuk mempengaruhi pemilih agar tidak menggunakan hak pilih, menggunakan hak pilih dengan cara tertentu sehingga suara menja- di tidak sah, memilih calon tertentu, atau tidak memilih calon tertentu sebagaimana dimaksud dalam Pasal 73 ayat (4) dipidana dengan pidana penjara paling singkat 36 (tiga puluh enam) bulan dan paling lama 72 (tujuh puluh dua) bulan dan denda paling sedikit Rp200.000.000,00 (dua ratus juta rupiah) dan paling banyak Rp1.000.000.000,00 (satu milyar rupiah).

(2) Pidana yang sama diterapkan kepada pemilih yang dengan sengaja melakukan perbuatan melawan hukum menerima pemberian atau janji sebagaimana dimaksud pada ayat (1).

Pasal 187B

Anggota Partai Politik atau anggota gabungan Partai Politik yang dengan sengaja melakukan perbuatan melawan hukum menerima imbalan dalam bentuk apapun pada proses pencalonan Gubernur dan Wakil Gubernur, Bupati dan Wakil Bupati, serta Walikota dan Wakil Walikota sebagaimana dimaksud dalam Pasal 47 ayat (1) dipidana dengan pidana penjara paling singkat 36 (tiga puluh enam) bulan dan paling lama 72 (tujuh puluh dua) bulan dan denda paling sedikit Rp300.000.000,00 (tiga ratus juta rupiah) dan paling banyak Rp1.000.000.000,00 (satu milyar rupiah).

\section{Pasal 187C}

Setiap orang atau lembaga yang terbukti dengan sengaja melakukan perbuatan melawan hukum memberi imbalan pada proses pencalonan Gubernur dan Wakil Gubernur, Bupati dan Wakil Bupati, serta Walikota dan Wakil Walikota maka penetapan sebagai calon, pasangan calon terpilih, atau sebagai Gubernur,Wakil Gubernur, Bupati, Wakil Bupati, Walikota atau Wakil Walikota sebagaimana dimaksud dalam Pasal 47 ayat (5), dipidana dengan pidana penjara paling singkat 24 (dua puluh empat) bulan dan pidana penjara paling lama 60 (enam puluh) bulan dan denda paling sedikit Rp300.000.000,00 (tiga ratus juta rupiah) dan paling banyak $\mathrm{Rp}$ 1.000.000.000,00 (satu milyar rupiah).

\section{Pasal 187D}

Pengurus lembaga pemantau Pemilihan yang melanggar ketentuan larangan sebagaimana dimaksud dalam Pasal 128, dipidana dengan pidana penjara paling 
singkat 36 (tiga puluh enam) bulan dan paling lama 72 (tujuh puluh dua) bulan dan denda paling sedikit Rp36.000.000,00 (tiga puluh enam juta rupiah) dan paling banyak Rp72.000.000,00 (tujuh puluh dua juta rupiah).

Pada pasal-pasal tersebut sangat jelas disebutkan tentang setiap orang yang dengan sengaja menjanjikan sesuatu kepada pemilih, mempengaruhi pemilih untuk menggunakan atau tidak menggunakan hak pilihnya sehingga suara menjadi tidak sah (pasal 187A, 1). Pada ayat 2 , disebutkan tentang hukuman yang sama diberikan kepada penerima seperti yang disebutkan pada ayat 1 . Pada pasal 187B disebutkan barang siapa yang menerima imbalan dalam bentuk apapun dalam proses pencalonan kepala daerah diganjar pidana serendah-rendahnya 36 bulan dan setinggi-tingginya 72 bulan. Selain ganjaran kurungan badan juga dikenai denda sekurang-kurangnya 300 juta rupiah dan setinggi-tingginya 1 miliar rupiah. Hukuman yang sama juga diberikan kepada seseorang yang memberi sesuatu imbalan dalam bentuk apapun dalam proses pencalonan kepala daerah. Sedangkan bagi pengurus lembaga pemantau pemilihan yang melanggar akan dikenakan pidana sekurang-kurangnya selama 36 bulan dan setinggi-tingginya 72 bulan. Selain hukuman kurungan juga dikenakan sangsi berupa denda sekurang-kurangnya 36 juta rupiah dan setinggi-tingginya 72 juta rupiah.

\subsection{Contoh Kasus di Indonesia}

Pengakuan yang menghentak publik disampaikan oleh La Nyalla Mattalitti, seorang bakal calon gubernur Jawa Timur. La Nyalla mengaku telah mengeluarkan uang sebesar Rp 5,9 Miliar yang diminta oleh pengurus DPD I Partai Gerindra Jawa Timur. Nyalla pun telah mengeluarkan cek sebesar Rp 70 Miliar yang dapat dicairkan jika rekomendasi sudah ada ditangan. Malang tak dapat ditolak mujur tak dapat diraih. Rekomendasi tak kunjung diterima sampai tanggal batas pengajuan bakal calon ditutup oleh KPUD.

Sebuah lembaga yang tergabung dalam Sentra Penegakan Hukum Terpadu (Gakkumdu) melakukan investigasi terhadap dugaan mahar politik. Gakkumdu ini mengambil contoh dalam penerbitan rekomendasi pencalonan La Nyalla Mattalitti di pemilihan kepala daerah (Pilkada) di Jawa Timur. Sayangnya, Nyalla tidak hadir dalam tiga kali pemanggilan pemeriksaan oleh Badan Pengawas Pemilihan Umum (Bawaslu) Jatim.

Selain pengakuan dari La Nyalla Mattalitti, ICW juga menemukan bahwa pada Pilkada Jawa Barat, Dedi Mulyadi mengaku diminta uang Rp 10 miliar oleh oknum di Partai Golkar.

Di Cirebon, Jawa Barat, Siswandi seorang pensiunan Polri berpangkat brigadir jenderal juga gagal melaju ke pencalonan walikota karena tidak mampu memenuhi permintaan sejumlah uang oleh pengurus DPD II PKS sebagai mahar politik. Siswandi pun bernyanyi di berbagai media menumpahkan kekesalannya.

Bahkan, gara-gara mahar politik, Partai Hanura secara mengejutkan terguncang prahara dengan mendongkel ketua umumnya Oesman Sapta Odang (OSO) karena diduga menilep uang mahar politik sebesar Rp 200 Miliar, masuk ke kantong pribadi sang ketua umum. Tidak perlu waktu lama, OSO pun tersungkur melalui mosi tidak percaya yang dilancarkan oleh 27 DPD I dan 401 DPC II pengurus Partai Hanura di perbagai daerah. Pendukung Sudding (lawan kubu OSO) segera menggelar Musyawarah Luar Biasa (Munaslub) Partai Hanura yang dilaksanakan di Hotel Sultan, Jakarta Selatan, dengan agenda tunggal pemilihan ketua umum setelah OSO dipecat pada rapat pengurus DPP Partai Hanura di hari sebelumnya.

Di Kabupaten Batubara, Sumatera Utara, Budi Heriyanto Dalimunthe juga gagal maju sebagai bakal calon Wakil Walikota karena diminta setor mahar politik sebanyak Rp 3 Miliar oleh pengurus Partai Golkar. Demikian pula di Kota Palangka Raya, Kalimantan Tengah, Jhon Krisli dan Maryono pasangan bakal calon Wali Kota dan Wakil Wali Kota Palangka Raya dari PDI-P batal mencalonkan diri karena dimintai ratusan juta perkursi DPRD.

Korban mahar politik di atas, hanya segelintir dari jejak digital yang terurai diperbagai media, tetapi cukup mewakili suara mayoritas diam (silent majority) selain pengakuan yang gagal maju dan "bernyanyi". Praktik mahar politik yang dilakukan parpol dan calon berisiko se- 
cara hukum berupa pencoretan dalam pencalonan karena melakukan tindak pidana pilkada yang melanggar ketentuan Pasal 7 ayat (2) huruf i, Pasal 45 ayat (2) huruf b angka 4, dan Pasal 187C terkait perbuatan tercela dan penerimaan imbalan yang tegas dilarang oleh UU No. 10 Tahun 2016 tentang Pilkada dan sanksi yang berat baik pemberi maupun penerima (parpol).

Praktik mahar politik sama jahatnya dengan penggunaan pengaruh karena kedudukannya sebagai pejabat negara atau aparat penegak hukum, yang mengancam akan mempersoalkan secara hukum atau mengkonversi politik tanpa mahar dengan perbagai jabatan menggiurkan di pemerintahan. Inilah muka bopeng demokrasi elektoral yang bertentangan dengan nilai etika dan moral politik serta melahirkan berbagai petaka politik nasional maupun daerah.

Mahfud MD memberikan komentar terkait mahar politik dalam Pilkada di Indonesia seperti yang dilansir dalam akun YouTube@Indonesia Lawyers Club tvOne yang diunggah pada Selasa (16/1/2018). Mahfud MD membeberkan beberapa fakta mengejutkan tentang beberapa pemilihan kepala daerah di Indonesia. pendapat Mahfud MD dapat dirangkum sebagai berikut :

\section{Diminta Jadi Cagub}

Mahfud MD mengungkapkan bahwa ia diminta oleh beberapa partai seperti PAN, Gerindra, dan PKS untuk menjadi calon gubernur di Jawa Timur. Mahfud MD, menyatakan bahwa mereka berulang kali menemuinya untuk hal tersebut. Akan tetapi Mahfud MD menolak hal tersebut karena merasa tidak siap menjadi calon gubernur.

2. Tidak Semua Calon Dimintai Mahar

Mahfud MD menuturkan, bahwa selama ini ia tidak dimintai uang. Sehingga ia menyebutkan bahwa menurutnya tidak semua orang atau semua calon dimintai uang mahar oleh partai politik. "Nah jadi, dalam konteks ini, tidak semua orang yang diajak untuk menjadi calon, dimintai uang," ungkapnya.

3. Yakin Bahwa Calon Pasti Menyediakan Uang

Sepengetahuan Mahfud MD, meski bukan dalam bentuk mahar atau dimintai uang, setiap calon kepala daerah baik bupati maupun gubernur pasti menyediakan uang. Mahfud MD menyatakan uang tersebut sesuai dengan jumlah kursi dukungan. "Hampir semua calon-calon kepala daerah yang saya kenal, yang mencalonkan diri sebagai kepala daerah, pasti menyediakan uang sesuai jumlah kursi dukungan. Misal, saya (Mahfud MD) punya kursi di DPRD sebanyak 5 itu harganya 2,5 miliar untuk provinsi, itu semua calonnya bilang kepada saya," Meski para pengurus partai di pusat menyatakan tidak ada mahar dan bersih dari mahar, tapi kenyataannya di daerah menghitung kursi.

\section{Jumlah Uang}

Mahfud MD juga membeberkan berapa jumlah uang yang disediakan oleh para calon kepala daerah. Menurutnya, dalam tingkat daerah seperti kabupaten, calon biasa menyediakan uang kira-kira sebanyak 200-250 juta rupiah. Sedangkan dalam tingkat gubernur uang tersebut antara 500 juta hingga 1 miliar rupiah. Hal tersebut tergantung dengan wilayah provinsinya, besar atau tidak.

\section{Tindak Pidana}

Menurut Mahfud MD, ada beberapa calon yang sudah memberikan uang, tapi tidak jadi diusung, sehingga membuka hal tersebut ke publik. Akan tetapi ada juga yang tidak membuka ke publik lantaran hal tersebut termasuk tindak pidana. "Banyak juga yang tidak membuka ke publik, karena itu sebenarnya tindak pidana, kalau sudah tawar menawar begitu, apalagi jika sudah memberi dan menerima, itu kan termasuk tindak pidana, bisa dipidana, sehingga banyak yang diam dan bilang tak ada uang-uang dalam hal ini," beber Mahfud MD.

\subsection{Kelemahan Badan Pengawas Pemi- lu (Bawaslu)}

Mahar politik dapat digolongkan peristiwa pidana, sama seperti pidana umum lainnya karena telah terjadinya peristiwa penyuapan atau pemberian yang mengakibatkan sistem atau aturan tidak berjalan secara normal. Namun mengingat peristiwa mahar tersebut berada pada wilayah pemilihan umum maka berdasaran prinsip hukum berupa Lex specialis derogat legi generali menyatakan bahwa hukum yang bersifat khusus (lex specialis) mengesa- 
mpingkan hukum yang bersifat umum (lex generalis). Sebuah penafsiran umum yang telah disepakati dan selalu diikuti dalam proses peradilan khususnya di Indonesia.

Berdasarkan prinsip hukum berupa Lex specialis derogat legi generali tersebut, Bawaslu (Badan Pengawas Pemilihan Umum) diberikan hak dan kewajiban untuk mengawasi jalannya proses pemilihan umum sehingga dapat berjalan sesuai dengan aturaan yang telah ditentukan oleh Undang-Undang dan peraturan KPU. Namun kenyataan memperlihatkan lain. Telah terjadi peristiwa memalukan yang dilakukan oleh seorang calon maupun oleh partai politik. Peristiwa tersebut berupa mahar politik yang sangat sulit dijatuhi sangsi oleh Bawaslu sebagai lembaga pengawas pemilu.

Direktur Eksekutif Perkumpulan untuk Pemilu dan Demokrasi (Perludem) Titi Anggraini mengatakan bahwa, Bawaslu memang memiliki kelemahan dalam penanganan dugaan mahar politik (politik uang). Menurut Titi Anggraini "Kelemahan Bawaslu adalah, mereka tidak punya daya paksa untuk menghadirkan saksi atau orang yang mau dimintai keterangan".

Penulis berpendapat bahwa penanganan kasus dugaan mahar politik ini semestinya ditempatkan sebagai bagian dari pembangunan optimisme publik dimana penegakan hukum tidak boleh mandek. Harus ada kejelasan terhadap apa yang terjadi. Bawaslu juga harus terbuka untuk menjelaskan apa pun hasil dari penanganan kasus dugaan mahar politik ini. Misalnya, jika hasilnya dinyatakan tidak cukup bukti, publik perlu diberitahu apakah bukti yang sudah didapatkan masih kurang. Informasi yang sudah berhasil dikumpulkan juga harus disampaikan secara terbuka ke publik sehingga diketahui siapa berbuat apa.

Indonesia Corruption Watch (ICW) bahkan mendorong Badan Pengawas Pemilu (Bawaslu) untuk proaktif menindaklanjuti dugaan pemberian mahar politik dalam proses pencalonan pada Pemilihan Kepala Daerah Serentak 2018. Menurut ICW, calon dan partai politik yang memberi dan menerima mahar harus ditindak tegas. Apalagi, larangan soal mahar ini sudah diatur secara tegas dalam Pasal 47 Undang-Undang Nomor 10 Tahun 2016 tentang Pemilihan Gubernur, Bupati dan Wali
Kota. Pasal 47 Undang-Undang Nomor 10 Tahun 2016 yang menyebutkan bahwa:

Pasal 47

(1) Partai Politik atau gabungan Partai Politik dilarang menerima imbalan dalam bentuk apapun pada proses pencalonan Gubernur, Bupati, dan Walikota.

(2) Dalam hal Partai Politik atau gabungan Partai Politik terbukti menerima imbalan sebagaimana dimaksud pada ayat (1), Partai Politik atau gabungan Partai Politik yang bersangkutan dilarang mengajukan calon pada periode berikutnya di daerah yang sama.

(3) Partai Politik atau gabungan Partai Politik yang menerima imbalan sebagaimana dimaksud pada ayat (2) harus dibuktikan dengan putusan pengadilan yang telah mempunyai kekuatan hukum tetap.

(4) Setiap orang atau lembaga dilarang memberi imbalan kepada Partai Politik atau gabungan Partai Politik dalam bentuk apapun dalam proses pencalonan Gubernur, Bupati, dan Walikota.

(5) Dalam hal putusan pengadilan yang telah mempunyai kekuatan hukum tetap menyatakan setiap orang atau lembaga terbukti memberi imbalan pada proses pencalonan Gubernur, Bupati, atau Walikota maka penetapan sebagai calon, calon terpilih, atau sebagai Gubernur, Bupati, atau Walikota dibatalkan.

Peneliti ICW dari Divisi Korupsi Politik, Almas Syafrina di Sekretariat ICW, mengatakan bahwa "Ancaman sanksi tergolong berat, baik bagi partai politik selaku penerima dan bakal calon selaku pemberi," Bagi pasangan calon yang memberikan mahar, apabila terbukti, maka pencalonannya dibatalkan. Hal ini sesuai pasal 47 Ayat 5 UU Pilkada. Sementara bagi partai politik penerima mahar, akan dilarang mengajukan calon pada periode berikutnya di daerah yang sama. Ini diatur dalam pasal 47 Ayat 2 UU Pilkada.

\subsection{Tawaran solusi untuk mengurangi terjadinya Politik Mahar di Indo- nesia}

David Easton (1950) mengemukan 
bahwa kehidupan politik sebagai sebuah sistem dari berbagai kegiatan yang saling berhubungan dan mempengaruhi cara pembuatan kebijakan (policy decision). Hubungan yang saling mempengaruhi antar lembaga kemudian disebut sebagai sistem politik yang dipengaruhi lingkungan eksternal.

Melihat peristiwa politik di atas, didapat beberapa permasalahan yang perlu dilakukan penataan ulang dalam sistem politik untuk mengatasi permasalahan kehidupan politik. Penataan ulang yang dimaksud adalah :

1. Kejahatan politik berupa setoran mahar politik yang sering dihaluskan sebagai uang saksi. Hal ini disebabkan karena Partai politik selama ini hanya menerima bantuan dana dari pemerintah yang dinilai sangat kurang untuk membiayai operasional partai dan kesekretariatan. Sudah saatnya kita menimbang sebuah sistem pendanaan parpol dalam suatu undang-undang dengan membiayai parpol dari APBN sebesar Rp 1 Triliun sampai Rp 2 Triliun perpartai atau minimal 50\% dari kebutuhan parpol diiringi dengan mekanisme pertanggungjawaban yang ketat dan penegakan hukum terhadap pelanggaran penggunaan APBN. Penulis berpendapat, kebijakan tersebut jauh lebih menguntungkan daripada menggunakan bancakan APBN untuk kepentingan parpol atau pribadi hingga puluhan triliun seperti kasus Nazaruddin dan Setya Novanto. Fakta di lapangan memperlihatkan bahwa peristiwa mahar politik juga diakibatkan karena mahalnya biaya politik yang harus dikeluarkan oleh parpol mapun calon kepala daerah. Mulai dari masa persiapan, biaya atribut dan kampanye, biaya saksi, membayar parpol, dan lain-lain yang ditaksir puluhan hingga ratusan miliar tergantung luasan, jumlah penduduk dan "basah atau keringnya" daerah.

2. Perlunya memuat ketentuan tegas larangan penggunaan pengaruh karena kedudukan atau jabatan dalam pelaksanaan pilkada dengan sanksi tegas dan pemidanaan dengan ancaman hukuman maksimal atas pelanggaran yang dimaksud. Baik pengaturannya terkait dengan UU Pemerintahan Daerah, UU
Aparatur Sipil Negara, UU Kepolisian, UU TNI, UU Kejaksaan, maupun UU Kementerian Negara atau UU yang terkait dengan jabatan publik yang dinilai dapat memengaruhi jalannya pilkada karena upaya kriminalisasi.

3. Perlunya peningkatan peran nyata partai politik khususnya dalam fungsi pendidikan politik terhadap masyarakat dan pengkaderan berkelanjutan bagi kader parpol untuk dipersiapkan sebagai calon pemimpin politik baik dalam pilkada maupun pilpres. Pencalonan non kader parpol sering kali menjadi pemantik konflik internal karena mencalonkan non kader sementara kader sendiri diabaikan hanya karena pertimbangan kemampuan finansial. Disamping itu, parpol juga harus mendidik masyarakat tentang bahaya politik uang dalam momentum pilkada atau pilpres agar pemilih tidak berorientasi materialis dan calon tidak bergantung kepada para cukong politik.

4. Perlunya payung hukum berupa undang-undang yang memberikan peluang yang lebih tegas kepada Bawaslu sehingga kedudukan Bawaslu sebagai badan pengawas pemilu dapat lebih kuat. Saat ini dirasakan bahwa keberadaan Bawaslu sangat lemah, karena Bawaslu tidak memiliki daya paksa untuk menghadirkan saksi atau orang yang mau dimintai keterangan.

\section{PENUTUP}

\subsection{Simpulan}

Berdasarkan uraian yang telah dibahas, dapat disimpulan antara lain :

1. Penyebab terjadinya Politik Mahar di Indonesia adalah besarnya biaya operasional partai politik di Indonesia dan kurangnya hibah dana yang diterima oleh partai politik dari pemerintah. Hal ini memaksa kader partai untuk mencari dana atas nama biaya saksi, biaya kampanye dan lain-lain.

2. Atran-aturan yang sudah diamanatkan dalam Undang-Undang dan larangan penggunaan pengaruh berupa kedudukan atau jabatan dalam pelaksanaan pemilihan umum sudah sangat jelas dan rinci. Mulai dari Pasal 6A ayat 
2 UUD 1945, UU Nomor 10 Tahun 2016 Tentang Perubahan kedua atas undang-undang nomor 1 tahun 2015 Tentang penetapan Perppu Nomor 1 tahun 2014 tentang pemilihan gubernur, bupati, dan walikota khususnya pada Pasal 47, Pasal 187A, Pasal 187B, Pasal 187C dan Pasal 187D.

3. Beberapa contoh kasus dapat dilihat pada beberapa kejadian dan pengakuan yang telah dipublikasi di media masa diantaranya adalah pengakuan dari La Nyalla Mattalitti, seorang bakal calon gubernur Jawa Timur yang mengaku telah mengeluarkan uang sebesar Rp 5,9 Miliar kepada pengurus DPD I Partai Gerindra Jawa Timur, Siswandi pensiunan Polri gagal dalam pencalonan walikota Cirebon, Partai Hanura terguncang prahara pendongkelan ketua umum Oesman Sapta Odang (OSO) karena diduga menilep uang mahar politik sebesar Rp 200 Miliar, Budi Heriyanto Dalimunthe gagal maju sebagai bakal calon Wakil Walikota di Kabupaten Batubara, Sumatera Utara karena diminta mahar politik sebanyak Rp 3 Miliar oleh pengurus Partai Golkar. Uraian di atas merupakan uraian kecil dari banyak kasus mahar politik yang terjadi di Indonesia namun tidak terungkap.

\subsection{Saran-saran}

Saran-saran yang penulis sampaikan merupakan tawaran solusi untuk mengurangi terjadinya Politik Mahar di Indonesia yaitu:

1. Sudah saatnya kita menimbang sebuah sistem pendanaan parpol dalam suatu undang-undang dengan membiayai parpol dari APBN sebesar Rp 1 Triliun sampai Rp 2 Triliun per partai atau minimal 50\% dari kebutuhan parpol, diiringi dengan mekanisme pertanggungjawaban yang ketat dan penegakan hukum terhadap pelanggaran penggunaan APBN.

2. Perlunya memuat ketentuan tegas larangan penggunaan pengaruh karena kedudukan atau jabatan dalam pelaksanaan pilkada melalui sanksi tegas dan pemidanaan dengan ancaman hukuman maksimal atas pelanggaran yang dimaksud.
3. Peningkatan peran nyata partai politik khususnya dalam fungsi pendidikan politik terhadap masyarakat dan pengkaderan berkelanjutan bagi kader parpol untuk dipersiapkan sebagai calon pemimpin politik baik dalam pilkada maupun pilpres.

4. Perlunya payung hukum berupa undang-undang yang memberikan peluang yang lebih tegas kepada Bawaslu sehingga kedudukan Bawaslu sebagai badan pengawas pemilu dapat lebih kuat.

\section{DAFTAR PUSTAKA}

Al-Barry, Dahlan Yacum M. 2001. Kamus Sosiologi Antropologi. Surabaya: Indah.

Arikunto, Suharsimi. 2002. Prosedur Penelitian Sebuah Pendekatan Praktek. Jakarta: Rineka Cipta.

Beilharz, Peter. 2003. Teori-Teori Sosial: Observasi Kritis terhadap para Filosof Terkemuka. Yogyakarta: Pustaka Pelajar.

Campbell, Tom. 1994. Tujuh Teori Sosial. Sketsa, Penilaian, Perbandingan. Yogyakarta: Kanisius.

Departemen Pendidikan Nasional. 2005. Kamus Besar Bahasa Indonesia. Jakarta: Balai Pustaka.

Estu Suryowati, 2018, Dimulai, Investigasi Dugaan Mahar Politik La Nyalla untuk Gerindra, https:// nasional. kompas.com/ read/2018/01/31/18434251/dimulai-investi gasi-dugaan-mahar-politik-la-nyalla-untuk-gerindra.

Ihsanuddin, 2018, Mahar Politik, Ini Sanksi yang Bisa Dikenakan ke Calon dan Parpol, https: // nasional. kompas. $\mathrm{com} / \mathrm{read} / 2018 / 01 / 16 / 16123881 /$ mahar-politik-ini-sanksi-yang-bisadikenakan-ke-calon-dan-parpol.

Lailatun Niqmah, 2018, Soal Mahar Politik, Mahfud MD Ungkap Fakta Mengejutkan, http: //www. Tribunnews.com/nasional/ 2018/01/17/terkait-mahar-politik-mahfud-md-ungkap-fakta-mengejutkan 
Miles \& Huberman A. 1992. Analisis Data Kualitatif. Jakarta: Universitas Indonesia.

Mulyana, Deddy. 2001. Metodologi Penelitian Kualitatif Paradigma Baru Ilmu Komunikasi dan Ilmu Sosial Lainnya. Bandung: Remaja Rosdakarya.

Robertus Belarminus, 2018, Kemendagri: Mahar Politik Racun Dalam Pelaksanaan Demokrasi, https:// nasional.kompas.com/ read/2018/03/03/21035491/kemendagri-mahar-politik-racun-dalam-pelaksanaan-demokrasi.
Sanderson, Stephen K. 2003. Makrososiologi, Sebuah Pendekatan terhadap Realitas Sosial. Jakarta: PT Raja Grafindo Persada.

Syamsuddin Radjab, 2018, Petaka Mahar Politik, http://www. tribunnews.com/ tribunners /2018/01/26/petaka-mahar-politik

Tim Permata Press, 2011, UUD 1945 Amandemen I, II, III, \& IV, Permata Press.

Yesmil Anwar dan Adang, 2008. Pengantar Sosiologi Hukum. Grasindo, PT. Gramedia Widiasarana Indonesia. 